\title{
THE EFFECT OF FINANCIAL LEVERAGE ON OPERATING PERFORMANCE: EVIDENCE FROM THE CZECH REPUBLIC*
}

\section{Zdeněk Toušek ${ }^{a}$ (D), Barbora Malinskáb (iD, Martin Prokop ${ }^{c}$, David Procházkad ${ }^{\text {iD }}$}

\begin{abstract}
The paper investigates the relationship of financial leverage and operating performance in a small open economy. A comprehensive sample consists of panel data from 1,821 Czech firms over the period 2006 to 2017. We find that leverage has a negative effect on the operating performance for the entire sample as well as for subsamples structured according to size or sector. We also find evidence that the relationship between leverage and performance in some sectors and segments is weakened during periods of economic downturn, as well as during the recent foreign exchange interventions of the Czech National Bank. Our study, focusing on the banking perspective, contributes to the debate about the impact of differences in leverage across sectors and segments on the capital allocation channels, managed in small open economies predominantly by banks.
\end{abstract}

Keywords: Financial leverage, operating performance, firm size, Czech Republic JEL Classification: C20, D20, G33

\footnotetext{
* We would like to thank Česká spořitelna a.s. for its support and for making its internal client database available for this research. This paper and its conclusions solely represent the authors' opinions and do not represent any official statement of Česká spořitelna a.s.

The paper was made under the institutional support of the Faculty of Finance and Accounting, Prague University of Economics and Business.

a Czech University of Life Sciences Prague, Department of Trade and Finance and Česká spořitelna a.s., Prague, Czech Republic

b Institute of Economic Studies, Faculty of Social Sciences, Charles University in Prague and Česká spořitelna a.s., Prague, Czech Republic

c Česká spořitelna a.s., Prague, Czech Republic

d Faculty of Finance and Accounting, Prague University of Economics and Business, Prague, Czech Republic

Email: TousekZ@pef.czu.cz,@csas.cz,BMalinska@csas.cz,MProkop@csas.cz,prochazd@vse.cz
} 


\section{Introduction}

The ongoing debate over whether leverage choice is predetermined by country- or firmspecific factors provides mixed empirical evidence. Psillaki and Daskalakis (2009) reveal that capital structure determinants of Greek, French, Italian, and Portuguese small and medium-sized enterprises possess common features. Delcoure (2007) provides empirical evidence proving that CEE firms follow a modified pecking order theory when deciding on capital structure. However, the decision is driven by a variety of individual factors and their interactions. The magnitude of firm-specific differences in leverage is also identified by de Jong et al. (2008) across 42 countries, where the country specifics shaping the firmspecific factors determining capital structure are found to be inconsistent with traditional capital structure theories. One of the perspectives where capital structure is relevant is firm performance. Empirical studies offer, more or less, proof of the links between these two phenomena as assumed by particular theories (Short, 1994). The relationship between capital structure and performance is driven by the level of leverage, firm size and asset structure (Margaritis and Psillaki, 2008) and ownership characteristics (Margaritis and Psillaki, 2010). Company size may influence the interest rates offered by banks (Moore and Craigwell, 2003), thus shaping the decision concerning the composition of capital structure, conditioned by the functionality of the national capital market and financial system (Denis and Mihov, 2003).

This paper aims to investigate the effect of company size and industry on the relationship between financial leverage and operating performance of Czech firms. The Czech Republic has been selected for several reasons. Firstly, the transition from a communist regime to a free market economy is still a work in progress. Secondly, the economy relies heavily on the presence of foreign direct investments. Thirdly, the Czech Republic has its own currency which exposes Czech firms, affiliated with global production and selling networks, to a significant foreign exchange risk. Fourthly, the CNB's exchange rate commitment significantly raised the amount of Czech currency in the economy and commercial banks have had to intensively search for ways to utilise this excess liquidity.

Such conditions create a unique setting under which companies determine their capital structure and its contribution to targeted performance. The relation of leverage and performance is also relevant for banks when assessing clients' credit risk and determining the risk premium. Our paper extends previous studies in the CEE region focusing only on determinants of capital structure, either in a cross-country context (Delcoure, 2007; Jõeveer, 2013; Mateev et al., 2013) or in a national context (Colombo, 2001; Bauer, 2004; Mazur, 2007; Črnigoj and Mramor, 2009), by relating capital structure with firm performance, conditioned by firm size and industry affiliation. Our paper utilises 
corporate data over a 12-year period, thus enabling the tracking of long-term trends of the investigated relation throughout distinct phases of economic and financial cycles.

This paper is further organised as follows. Section 2 summarises the most relevant underlying theoretical underpinnings and empirical findings. Section 3 introduces the research design. In Section 4, we present and discuss the results. Section 5 concludes the paper.

\section{Literature Review}

Classical theories of capital structure started with Modigliani and Miller (1958) claim- ing that the value of a company is independent of its capital structure on a perfect arbitrage-free capital market. After the introduction of real-life market imperfections such as taxes, or expected bankruptcy costs, Myers (1984) showed that under static trade-off theory, company value is dependent on debt ratio. The pecking order theory (Myers, 1984) introduced a funding hierarchy phenomenon, which is explained by the transaction and issuing cost argument. The signalling theory, using the asymmetric information argument, was developed by Ross (1977) and Harris and Raviv (1990), who focused on the relation of investors' information concerning a company's debt and their ability to oversee management.

Titman and Wessels (1988) found that short-run borrowings are negatively related to firm size due to the transaction costs small firms face when raising sources of long-term financing. The effect of size is also mentioned by Barclay and Smith (1995) or Faulkender and Petersen (2006). Titman and Wessels (1988), de Jong et al. (2008), Frank and Goyal (2009) or Vithessonthi and Tongurai (2015) have tackled the issue of the relationship between company returns and leverage, albeit with mixed outcomes. The ambiguity of the empirical results is, presumably, due to the various operating performance and financial leverage measures employed, different underlying datasets and statistical approaches applied. Furthermore, it is assumed that profitability of companies is dependent on leverage; however, some studies confirm both directions of dependence (Margaritis and Psillaki, 2010).

Some authors have elaborated the idea of differentiating capital structure with respect to alternative industrial sectors (Hall et al., 2000; MacKay and Phillips, 2005; Talberg et al., 2008; Vithessonthi and Tongurai, 2015). Hall et al. (2000) found a negative relationship between short-term financing and financial performance, with significant variation across industries, whilst profitability had no effect on long-term borrowing in any industry. Talberg et al. (2008) demonstrated significant differences in capital structure between different industries for companies quoted on the US stock exchange and showed a negative relationship between leverage and profitability. The authors found company size to be both positively and negatively related to leverage, depending on the size interval under examination. 
Capital structure determinants have also been investigated in Central and Eastern Europe. Colombo's study (2001) of 1,100 Hungarian firms in the early years after the fall of communism identified the existence of imperfections constraining the achievement of optimal structure. Mazur (2007), using a dataset of Polish listed firms over the period 2000-2004, focused on the testing of the static trade-off theory and the pecking order theory, where the latter dominated decisions involving capital structure. Črnigoj and Mramor (2009) validated both theories on a sample of Slovenian firms. The first crosscountry study on the CEE region by Delcoure (2007) did not find robust empirical evidence for any of the three classical theories, only some indicators supported the preference of a "modified" pecking order theory. Using data from nine CEE countries, Jõeveer (2013) revealed that leverage is determined by country-specific factors in the case of small unlisted companies, while company factors are decisive for explaining the differences in the leverage of listed and large unlisted companies.

Regarding the Czech Republic, the first evidence (596 firms in 1993-1997) of capital structure adjustments was provided by Nivorozhkin (2004). Bauer (2004) analysed the determinants of the capital structure of 72 listed Czech companies for the years 2000-2001 and provided evidence of a negative relationship of leverage and profitability and a positive association with size. Prášilová (2012) tested the capital structure of 299 Czech firms over the period 2006-2007. The results of the empirical analysis are mixed, partly confirming the trade-off as well as the pecking order theory, thereby suggesting their mutual co-existence.

Based on the literature review, we propose the following hypotheses:

H1a: There is a negative relationship between financial leverage and operating performance, with varying intensity across company size.

$\mathrm{H} 1 \mathrm{~b}$ : There is a negative relationship between financial leverage and operating performance, with varying intensity across company sectors.

$\mathrm{H} 2$ : An economic downturn affects the magnitude of the relationship between financial leverage and operating performance.

To the extent of our current knowledge, the literature examining the relationship between the financial leverage and operational performance of Czech firms is rather limited. The abovementioned studies focus more on the determinants of capital structure. Furthermore, the time period studied and the sample size investigated are quite limited. The only relevant study is by Mateev et al. (2013) on small and medium-sized firms from seven CEE countries for 2001-2005. The disadvantages of the study are that it does not cover large entities and is relatively outdated as it covers the period before the EU accession. This paper extends the literature by investigating the relation of leverage and operating performance by incorporating the effects of company size and industry over a period of 12 years, from 
2006 to 2017. Such a lengthy period provides the key advantage of covering the phases of considerable economic downturns and subsequent recoveries, strong economic growth, as well as 3.5 years of monetary expansion carried out by the Czech National Bank.

\section{Research Design}

\subsection{Raw data}

We use a dataset comprising the complete individual financial statements of selected corporate entities performing their business activities in the Czech Republic over the period 2006-2017 ${ }^{1}$. To avoid any composition effect (Xu, 2012), entities that did not exist during the entire twelve-year sample period, or those whose financial figures were not complete, are removed (Xu, 2012). As did Faulkender and Petersen (2006), we observed and removed several firms with extremely high leverage (above one). Companies with the NACE ${ }^{2}$ classifications $\mathrm{K}-\mathrm{U}$ were eliminated as these industries are specific and do not correspond to the standard nature of business for various reasons. After all adjustments, our dataset contains 1,821 companies with complete annual information for the period between 2006 and 2017, i.e., 21,852 firm-year observations. Details can be seen in Table 1.

Table 1: Sample composition

\begin{tabular}{l|c|c|c|c|c}
\hline Sector & Companies & Observations & Segment & Companies & Observations \\
\hline Agriculture & 269 & 3,228 & S1 & 363 & 4,356 \\
\hline Construction & 76 & 912 & S2 & 398 & 4,776 \\
\hline $\begin{array}{l}\text { Engineering \& } \\
\text { manufacturing }\end{array}$ & 195 & 2,340 & S3 & 555 & 6,660 \\
\hline Food \& beverages & 114 & 1,368 & S4 & 341 & 4,092 \\
\hline Wholesale \& retail & 420 & 5,040 & S5 & 164 & 1,968 \\
\hline Rest & 747 & 8,964 & $\mathrm{x}$ & $\mathrm{x}$ & $\mathrm{X}$ \\
\hline Total & $\mathbf{1 , 8 2 1}$ & $\mathbf{2 1 , 8 5 2}$ & & $\mathbf{1 , 8 2 1}$ & $\mathbf{2 1 , 8 5 2}$ \\
\hline
\end{tabular}

Source: Own calculation

Since we focus on the potential dependency of operating performance on leverage moderated by size, we divide our data into different segments according to turnover

1 Data were predominantly collected from the Commercial Register, www.or.justice.cz and internal sources of Česká spořitelna, a.s.

2 NACE stands for Nomenclature statistique des activités économiques dans

la Communauté européenne. 
at the end of the last fiscal year. We adopt segmentation based on the provider's system of client scoring into five segments, with smallest firms in Segment 1 (S1) with turnover up to 20 million CZK and largest firms in Segment 5 (S5) with turnover more than 2 billion CZK. Our approach is more cash flow-driven than the alternative asset-based size as used, e.g., by Faulkender and Petersen (2006) or Vithessonthi and Tongurai (2015). The turnover ranges correspond to the corporate client segmentation approach commonly used by local lending institutions and are considered valuable by senior debt providers for tuning lending procedures according to clients' needs.

\subsection{Descriptive analysis}

Prior to the actual regression-based examination of the effect of financial leverage on operating performance, we carefully analysed the statistical properties of the variables we were interested in (Table 2). The following variables are included: EST (number of years since the company establishment), TO (turnover in million CZK), EBITDA (earnings before income tax and depreciation in million CZK), EBITDA margin (calculated as EBITDA/TO), ROA (return on assets calculated as EBITDA/total assets) and BLAssets (leverage measured as bank loans/total assets). When referring to financial leverage in the context of the further analysis carried out in this paper, we refer to BLAssets ${ }^{3}$. Total bank loans are determined as short- and long-term bank loans granted by banks and other financial institutions, which are booked on balance. Bonds and shareholder loans as alternative financial sources have not been included in our calculation of total leverage as these financial sources represent only $0.37 \%$ of total assets in our sample. Off-balance liabilities (such as lease liabilities) are not included as information on them is not disclosed consistently by firms. To avoid any mismatch due to missing lease liabilities, EBITDA is used as a more suitable performance indicator.

The results do not fully correspond to theories assuming that larger companies tend to be more leveraged, such as by Barclay and Smith (1995), Faulkender and Petersen (2006). As depicted in Figure 1, the average leverage is 0.25 for the smallest company subsample (S1) and 0.18 for the largest company subsample (S5), i.e., $38 \%$ lower. The median figures confirm a similar path $(0.22$ versus 0.16$)$. Similarly, the average performance is highest for the smallest segment (S1) and decreases continuously as company size increases. The average EBITDA margin for $\mathrm{S} 1$ is 0.39 , which is almost 6 times greater than that of the largest companies in S5 (i.e., 0.07). An alternative metric of performance, ROA, yields a relatively stable result in magnitude across all segments ( 0.100 for S1 and similarly 0.097 for S5).

3 Alternative definitions of financial leverage include, for example, bank debt/EBITDA, typically employed by financial institutions in the indebtedness analysis or long-term bank loans/total assets, which is more oriented on long-term investment plans of companies. We chose BLAssets since the former loses coherent interpretation in case EBITDA $<=0$ and the latter omits working capital facilities, which are an important item of bank financing on firms' balance sheets. 
Table 2: Descriptive statistics according to company size

\begin{tabular}{|c|c|c|c|c|c|c|c|}
\hline Full sample & Mean & SD & Min & Median & Max & Skewness & Kurtosis \\
\hline EST & 15.58 & 6.47 & 0.00 & 16.00 & 66.00 & 0.68 & 2.97 \\
\hline TO & 662.30 & $4,416.58$ & 0.00 & 77.98 & $128,448.43$ & 17.15 & 356.49 \\
\hline EBITDA & 57.32 & $1,054.42$ & $-3,465.07$ & 5.30 & $66,011.00$ & 47.67 & $2,469.03$ \\
\hline EBITDA margin & 0.16 & 6.95 & -32.25 & 0.07 & $1,020.00$ & 144.87 & $21,240.60$ \\
\hline ROA & 0.10 & 0.11 & -2.55 & 0.09 & 1.40 & 0.19 & 27.25 \\
\hline BLAssets & 0.21 & 0.17 & 0.00 & 0.18 & 0.96 & 0.81 & 0.41 \\
\hline Segment_1 & Mean & SD & Min & Median & Max & Skewness & Kurtosis \\
\hline EST & 14.50 & 5.94 & 0.00 & 15.00 & 41.00 & -0.03 & -0.31 \\
\hline TO & 18.06 & 70.74 & 0.00 & 11.77 & $4,147.04$ & 46.65 & $2,667.40$ \\
\hline EBITDA & 1.77 & 10.26 & -572.36 & 0.96 & 158.16 & -38.21 & $2,265.93$ \\
\hline EBITDA margin & 0.39 & 15.48 & -32.25 & 0.08 & $1,020.00$ & 65.59 & $4,316.88$ \\
\hline ROA & 0.100 & 0.13 & -0.71 & 0.08 & 1.40 & 1.12 & 10.29 \\
\hline BLAssets & 0.25 & 0.20 & 0.00 & 0.22 & 0.96 & 0.68 & -0.19 \\
\hline Segment_2 & Mean & SD & Min & Median & Max & Skewness & Kurtosis \\
\hline EST & 15.07 & 6.46 & 0.00 & 15.00 & 66.00 & 1.00 & 5.93 \\
\hline TO & 41.41 & 31.54 & 0.63 & 35.44 & 529.97 & 5.82 & 60.61 \\
\hline EBITDA & 4.01 & 5.49 & -67.27 & 2.51 & 54.54 & 1.19 & 14.22 \\
\hline EBITDA margin & 0.10 & 0.13 & -1.20 & 0.07 & 1.11 & 0.49 & 9.02 \\
\hline ROA & 0.106 & 0.12 & -1.00 & 0.09 & 1.10 & 0.48 & 11.43 \\
\hline BLAssets & 0.21 & 0.17 & 0.00 & 0.18 & 0.93 & 0.89 & 0.61 \\
\hline Segment_3 & Mean & SD & Min & Median & Max & Skewness & Kurtosis \\
\hline EST & 15.94 & 6.84 & 0.00 & 16.00 & 55.00 & 0.78 & 2.06 \\
\hline TO & 117.31 & 71.99 & 0.06 & 101.48 & $1,049.24$ & 2.46 & 13.97 \\
\hline EBITDA & 11.37 & 14.96 & -166.51 & 6.95 & 175.35 & 1.47 & 13.92 \\
\hline EBITDA margin & 0.12 & 1.27 & -1.06 & 0.07 & 102.84 & 79.40 & $6,409.49$ \\
\hline ROA & 0.106 & 0.10 & -2.55 & 0.09 & 1.23 & -1.77 & 71.64 \\
\hline BLAssets & 0.18 & 0.15 & 0.00 & 0.16 & 0.93 & 0.68 & 0.02 \\
\hline Segment_4 & Mean & SD & Min & Median & Max & Skewness & Kurtosis \\
\hline EST & 16.17 & 6.28 & 1.00 & 16.00 & 60.00 & 0.82 & 4.36 \\
\hline TO & 454.55 & 288.23 & 0.40 & 395.27 & $5,164.19$ & 3.17 & 26.65 \\
\hline EBITDA & 34.47 & 47.43 & -757.21 & 22.56 & 771.25 & 3.14 & 59.31 \\
\hline EBITDA margin & 0.08 & 0.08 & -0.46 & 0.06 & 0.75 & 1.87 & 10.53 \\
\hline ROA & 0.109 & 0.09 & -0.42 & 0.09 & 0.75 & 1.41 & 7.28 \\
\hline BLAssets & 0.20 & 0.15 & 0.00 & 0.19 & 0.76 & 0.48 & -0.46 \\
\hline Segment_5 & Mean & SD & Min & Median & Max & Skewness & Kurtosis \\
\hline EST & 16.78 & 6.25 & 0.00 & 17.00 & 45.00 & 0.43 & 1.49 \\
\hline TO & $5,871.42$ & $13,652.37$ & 7.49 & $1,917.69$ & $128,448.43$ & 5.25 & 31.82 \\
\hline EBITDA & 512.67 & $3,480.76$ & $-3,465.07$ & 92.82 & $66,011.00$ & 14.32 & 220.55 \\
\hline EBITDA margin & 0.07 & 0.08 & -0.57 & 0.05 & 0.96 & 2.01 & 16.01 \\
\hline ROA & 0.097 & 0.08 & -0.38 & 0.09 & 0.56 & 0.74 & 5.71 \\
\hline BLAssets & 0.18 & 0.16 & 0.00 & 0.16 & 0.73 & 0.66 & -0.35 \\
\hline
\end{tabular}

Note: S1: TO < CZK 20 million; S2: CZK 20 million < TO < CZK 60 million; S3: CZK 60 million < TO < CZK 200 million; S4: CZK 200 million < TO < CZK 1,000 million; S5: TO > CZK 1.000 million

Source: Own calculation 
Figure 1: Average leverage and profitability by size segment

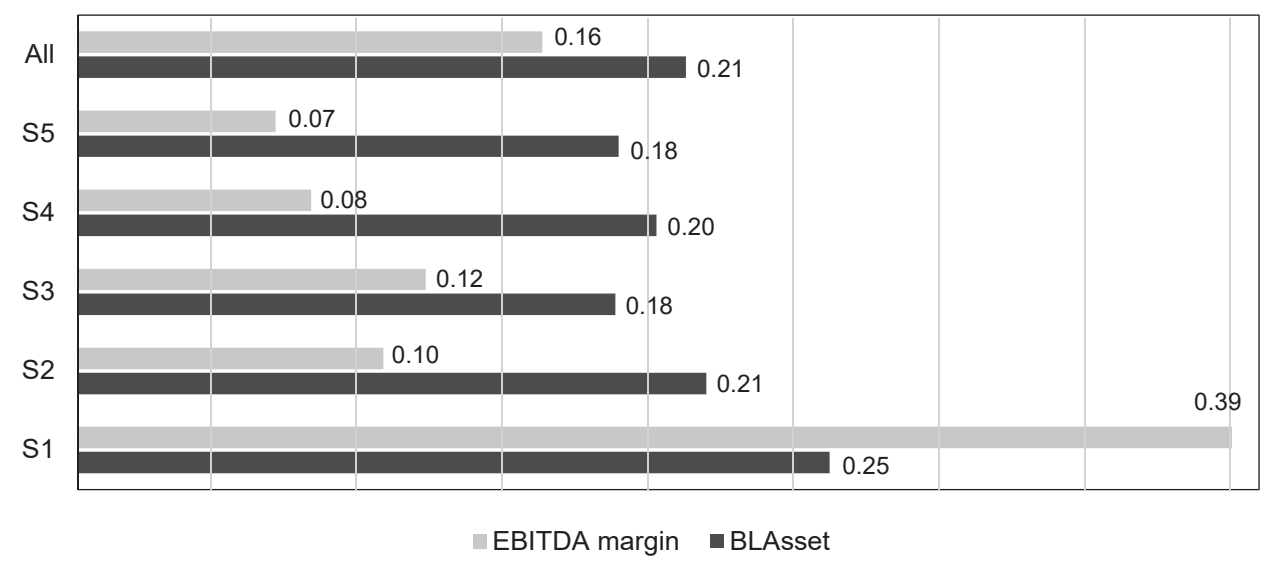

Source: Own calculation

Figure 2: Average leverage and profitability by sector and size segment (S = Small, L = Large)

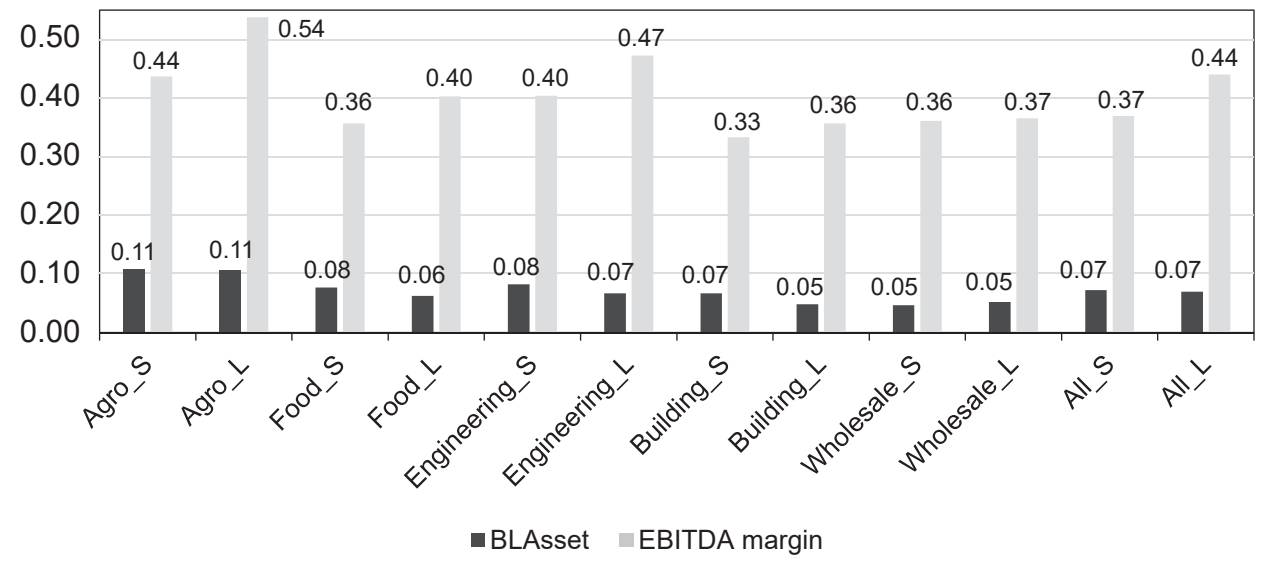

Source: Own calculation

The same descriptive analysis is run for the five main industrial sectors. Each sector is divided into two subsamples (large and small firms), with the median of turnover being the cutting point. Figure 2 shows differences in the average leverage BLAssets and the profitability EBITDA margin across selected sectors and size subsamples. Smaller companies are more leveraged (the average leverage for small firms is 0.22 versus 0.19 
for large firms in the full data sample). The same relation applies to all industry sectors with the exception of the Food sector. By analysing the underlying data, the share of bank financing in the total liabilities is higher for small companies (the average share of other financing in the total assets is $41.3 \%$ in S1) than for large companies (39.1\% in S5). Similarly, the equity ratio varies significantly across predefined segments (the average equity ratio for $\mathrm{S} 1$ is $33.2 \%$ compared to $42.6 \%$ for $\mathrm{S} 5$ ).

Together with metric (1) total bank loans/total assets (BLAssets), leverage is also calculated as (2) long-term bank loans/total assets (LTBLAssets), which is more oriented on long-term investment plans of companies, and finally as (3) bank debt/EBITDA (CFLev), typically employed by financial institutions in indebtedness analysis. Our alternative metrics extend the simplified approach of the majority of studies, e.g., Aivazian et al., (2005) or Mizen and Tsoukas (2012), defining leverage as a ratio of the book value of total liabilities to the book value of total assets due to a lack of detailed data. Although each metric suffers from certain shortcomings, all of them produce quite similar results ${ }^{4}$ in terms of direction and distribution across the selected segments.

\subsection{Methodology}

Adapting the approach of Vithessonthi and Tongurai (2015), the following model, showing the effect of financial leverage on operating performance while controlling for various company specific and macroeconomic variables, is used:

$$
R O A_{i t}=B L A s s e t s_{i t}+E S T_{i t}+T O_{i t}+E B I T D A_{i t}+G D P_{t}+3 M P R I B O R_{t}+v_{i}+\varepsilon_{i t}
$$

where return on assets $(R O A)$ is defined as EBITDA divided by total assets. The use of $E B I T D A$ in the profitability measure corresponds to common banking practice, which primarily focuses on the cash flow perspective, thus mitigating potential discrepancies resulting from application of various depreciation/amortisation schemes among individual firms compared to fully accrual measures (Šarlija and Harc, 2016).

The level of leverage is captured by the variable BLAssets. The company-specific controls include $E S T$ as a proxy for its market experience and lifecycle, $T O$ controls for the size of a company, and EBITDA controls for variations in financing models and a firm's ability to repay loans and interest charges. Economy-wide variables include $G D P$ growth and the $3 M P R I B O R$ benchmark interest rate to eliminate the effects of economic cycles on an individual firm's performance. The error term consists of $v$ and $\varepsilon$, which represent a company-specific and a disturbance term, respectively.

$4 \quad$ Untabulated results available upon request. 
The usual process of selection of the appropriate model for panel data is performed. First, by comparing the results of pooled ordinary least squares and a fixed-effects estimation, the hypothesis of no significant individual effects was rejected by an F-test ( $p$-value $<0.001)$. Further, the hypothesis of the consistency of both fixed-effects and random-effects models was tested. The zero hypothesis was rejected by a Hausman test ( $p$-value $<0.001)$, meaning that the random-effects model might yield inconsistent estimates. Based on the above, we employ an individual fixed-effects ordinary leastsquares model with panel-corrected standard errors, in particular a robust covariance matrix estimator according to Beck and Katz (1995), in order to mitigate serial correlation and heteroscedasticity of errors. Unit root tests are performed as well (with unit roots rejected). We have also inspected the methodology of time-fixed effects, which reported results for the effect of leverage on operating performance quite similar to those of an individual fixed-effects model. ${ }^{5}$

We also performed an analysis to rule out potential threat of multicollinearity. $3 M P R I B O R$ and GDP growth, being our key macroeconomic controls, might raise some concerns about their comovement bringing a multicollinearity issue to the model. We used a variance inflation factor (VIF) test for multicollinearity on the pooled model with the VIF value safely below 3 (VIF ranging from 1.0 to 1.6), which is perceived to be a conservative threshold for presence of strong correlation among predictors. Moreover, looking at the correlation matrix of the variables included in our model, the maximum value of the correlation coefficient does not exceed $60 \%$.

\section{Results and Discussion}

\subsection{Effect of leverage on operating performance: Company size perspective}

Table 3 presents the regression results of the effect of leverage on operating performance for the entire sample and for each size segment separately, obtained using R statistical software. In all segments, as well as for the whole sample, we detect a significant negative effect of leverage on operating performance. H1a is thus confirmed, which may suggest that the pecking order theory is relevant for companies included in the sample similarly to Mazur (2007) or Mateev et al. (2013). The explanation of a negative relation in Czech conditions can be twofold. Firstly, the average EBITDA of our sample had been decreasing since 2010, despite increasing average turnover and average total amount of bank loans drawn. Despite an economic boom commencing in 2014, the corporate segment was not 
able to maintain stable margins for many reasons, such as stronger competition, an increase in several direct cost items and the inability to reflect these in the final price. Secondly, the corporate sector reported an average revenue increase accompanied by higher working capital needs and higher investments in production capacities $(+30.5 \%$ of average CAPEX between 2006 and 2017). As the average EBITDA and the average operating profitability decreased during the same period, firms had to cover the negative balances in the operating and investment cash flows from external sources, mainly in the form of new interestbearing bank debt $(+5.8 \%$ of the average bank loans between 2006 and 2017).

Table 3: Effect of leverage on operating performance: analysis by size segment

\begin{tabular}{|c|c|c|c|c|c|c|c|}
\hline & All_Ind & All_Time & S1 & S2 & S3 & S4 & S5 \\
\hline BLAssets & $\begin{array}{c}-0.108^{* * *} \\
(0.008)\end{array}$ & $\begin{array}{c}-0.105^{* * *} \\
(0.008)\end{array}$ & $\begin{array}{c}-0.101^{* * *} \\
(0.014)\end{array}$ & $\begin{array}{c}-0.119^{* * *} \\
(0.014)\end{array}$ & $\begin{array}{c}-0.127^{* * *} \\
(0.013)\end{array}$ & $\begin{array}{c}-0.147^{* * *} \\
(0.016)\end{array}$ & $\begin{array}{c}-0.106^{* * *} \\
(0.024)\end{array}$ \\
\hline EBITDA & $\begin{array}{l}0.000^{* *} \\
(0.000)\end{array}$ & $\begin{array}{l}0.000 * * * \\
(0.000)\end{array}$ & $\begin{array}{l}0.005^{* * *} \\
(0.000)\end{array}$ & $\begin{array}{l}0.015^{* * *} \\
(0.000)\end{array}$ & $\begin{array}{l}0.005^{* * *} \\
(0.000)\end{array}$ & $\begin{array}{l}0.001^{* * *} \\
(0.000)\end{array}$ & $\begin{array}{l}0.000^{* *} \\
(0.000)\end{array}$ \\
\hline 3MPRIBOR & $\begin{array}{l}0.597^{* * *} \\
(0.088)\end{array}$ & - & $\begin{array}{c}0.320 \\
(0.204)\end{array}$ & $\begin{array}{l}0.387^{*} \\
(0.183)\end{array}$ & $\begin{array}{c}0.294^{*} \\
(0.137)\end{array}$ & $\begin{array}{l}0.507^{* * *} \\
(0.130)\end{array}$ & $\begin{array}{c}0.490 * \\
(0.196)\end{array}$ \\
\hline GDP & $\begin{array}{l}0.172^{* * *} \\
(0.031)\end{array}$ & - & $\begin{array}{c}0.154 \\
(0.081)\end{array}$ & $\begin{array}{c}0.083 \\
(0.059)\end{array}$ & $\begin{array}{l}0.239 * * * \\
(0.049)\end{array}$ & $\begin{array}{l}0.217^{* * *} \\
(0.046)\end{array}$ & $\begin{array}{c}0.105 \\
(0.063)\end{array}$ \\
\hline TO & $\begin{array}{c}0.000 \\
(0.000)\end{array}$ & $\begin{array}{c}0.000 \\
(0.000)\end{array}$ & $\begin{array}{l}0.001^{* * *} \\
(0.000)\end{array}$ & $\begin{array}{c}0.000 \\
(0.000)\end{array}$ & $\begin{array}{c}0.000 \\
(0.000)\end{array}$ & $\begin{array}{c}-0.000^{* * *} \\
(0.000)\end{array}$ & $\begin{array}{c}0.000 \\
(0.000)\end{array}$ \\
\hline EST & $\begin{array}{c}0.000 \\
(0.000)\end{array}$ & $\begin{array}{c}0.047 \\
(0.126)\end{array}$ & $\begin{array}{l}-0.001 \\
(0.001)\end{array}$ & $\begin{array}{c}-0.002^{*} \\
(0.001)\end{array}$ & $\begin{array}{c}-0.002^{* * *} \\
(0.001)\end{array}$ & $\begin{array}{c}0.000 \\
(0.001)\end{array}$ & $\begin{array}{c}0.000 \\
(0.001)\end{array}$ \\
\hline $\operatorname{Adj} . R^{2}$ & $34.6 \%$ & $34.9 \%$ & $39.0 \%$ & $55.0 \%$ & $54.1 \%$ & $59.7 \%$ & $52.5 \%$ \\
\hline
\end{tabular}

Note: ${ }^{* *} p<0.001 ;{ }^{* *} p<0.01 ;{ }^{*} p<0.05$, standard errors in parentheses

Source: Own calculation

The estimation results show a varying coefficient of leverage for different size segments. The negative effect of leverage on $R O A$ is strongest for mid-range companies classified in segments S3 (i.e., -0.127) and S4 (i.e., -0.147) and weakest on both tails of the spectrum: -0.101 under S1 and -0.106 under S5. Our results are consistent with those of Mateev et al. (2013), who found that larger firms were less dependent on external funding. Regarding the economic control variables, the interest rate indicator exhibits a significant positive effect on company performance in the whole sample and the effect also remains significant for all the segments, with the exception of S1. The economic 
environment had been experiencing a period with decreasing and, consequently, stable and low annual average interest rates (the 3-month PRIBOR dropped from $2.25 \%$ p.a. in 2006 to $0.76 \%$ p.a. in 2017). A reduction in overall debt service costs thus contributed to the identified increase in $R O A$. Unsurprisingly, the effect of $G D P$ on $R O A$ is significant and positive in the whole sample. The effect tends to be stronger for the middle segments, whereas the smallest and largest companies are not significantly exposed - on average to variations in economic growth.

Table 4: Effect of leverage on operating performance: alternative measures of leverage

\begin{tabular}{l|c|c|c}
\hline & Leverage 1 & Leverage 2 & Leverage 3 \\
\hline BLAssets & $\begin{array}{c}-0.108^{* * *} \\
(0.008)\end{array}$ & - & - \\
\hline LTBLAssets & - & $-0.055^{* * *}$ & - \\
\hline CFLev & - & - & 0.000 \\
\hline EBITDA & $0.000^{* *}$ & $0.000^{* *}$ & $0.000)$ \\
\hline 3MPRIBOR & $(0.000)$ & $(0.000)$ & $(0.000)$ \\
\hline GDP & $0.597^{* * *}$ & $0.594^{* * *}$ & $0.603^{* * *}$ \\
\hline TO & $(0.088)$ & $(0.089)$ & $(0.089)$ \\
\hline \multirow{2}{*}{ EST } & $0.172^{* * *}$ & $0.199^{* * *}$ & $0.208^{* * *}$ \\
& $(0.031)$ & $(0.031)$ & $(0.031)$ \\
\hline Adj. $\boldsymbol{R}^{2}$ & 0.000 & 0.000 & 0.000 \\
\hline
\end{tabular}

Note: ${ }^{* *} p<0.001 ;{ }^{* *} p<0.01 ;{ }^{*} p<0.05$, standard errors in parentheses

Source: Own calculation

The results for alternative measures of leverage are presented in Table 4 . The outcomes for LTBLAssets are consistent with BLAssets. However, the value of the coefficient is approximately $50 \%$ lower $(-0.108$ vs. -0.055$)$. This relation may suggest that interest rates for long-term loans are lower than those for short-term ones, which does not correspond to a standard loan pricing process. These findings may reveal imperfections in the Czech financial system, modifying the assumptions of the pecking order theory (Delcoure, 2007) by incorporating certain aspects of the trade-off theory in business practice (Prášilová, 
2012). Lacking the capabilities to manage capital structure effectively can be an alternative explanation. In the case of cash flow-based leverage CFLev, the regression model does not reveal any significant impact on operating profitability.

Regarding the firm-specific and macroeconomic control variables, all three models provide consistent estimates in terms of sign, magnitude and statistical significance.

\subsection{Effect of leverage on operating performance: Company sector perspective}

Table 5 summarises the estimation of Equation 1 across the industrial sector subsamples. The negative effect of leverage on $R O A$ proves to be significant for all the sectors. Our hypothesis H1b, that the intensity of the effect differs among sectors, is confirmed and consistent, e.g., with the findings of Prášilová (2012). The impact of leverage on performance is stronger in Engineering and Construction, with coefficients -0.191 and -0.146 being considerably larger than the average for the entire sample of -0.108 .

Table 5: Effect of leverage on operating performance: analysis by sector

\begin{tabular}{|c|c|c|c|c|c|c|}
\hline & All_Ind & Agriculture & Construction & Engineering & Food & Wholesale \\
\hline BLAssets & $\begin{array}{l}-0.108^{* * *} \\
(0.008)\end{array}$ & $\begin{array}{c}-0.085^{* * *} \\
(0.015)\end{array}$ & $\begin{array}{l}-0.146^{* * *} \\
(0.039)\end{array}$ & $\begin{array}{l}-0.191^{* * *} \\
(0.024)\end{array}$ & $\begin{array}{c}-0.069^{* *} \\
(0.025)\end{array}$ & $\begin{array}{l}-0.105^{* * *} \\
(0.015)\end{array}$ \\
\hline EBITDA & $\begin{array}{l}0.000^{* *} \\
(0.000)\end{array}$ & $\begin{array}{l}0.003^{* * *} \\
(0.000)\end{array}$ & $\begin{array}{l}0.003^{* * *} \\
(0.000)\end{array}$ & $\begin{array}{l}0.000^{* * *} \\
(0.000)\end{array}$ & $\begin{array}{l}0.001^{* * *} \\
(0.000)\end{array}$ & $\begin{array}{l}0.000 * * * \\
(0.000)\end{array}$ \\
\hline 3MPRIBOR & $\begin{array}{l}0.597^{* * *} \\
(0.088)\end{array}$ & $\begin{array}{c}0.104 \\
(0.134)\end{array}$ & $\begin{array}{l}1.094^{*} \\
(0.457)\end{array}$ & $\begin{array}{c}0.557 \\
(0.320)\end{array}$ & $\begin{array}{c}0.277 \\
(0.252)\end{array}$ & $\begin{array}{l}1.059^{* * *} \\
(0.160)\end{array}$ \\
\hline GDP & $\begin{array}{l}0.172^{* * *} \\
(0.031)\end{array}$ & $\begin{array}{l}-0.173^{* * *} \\
(0.052)\end{array}$ & $\begin{array}{c}0.266 \\
(0.168)\end{array}$ & $\begin{array}{c}0.115 \\
(0.095)\end{array}$ & $\begin{array}{l}0.226^{* *} \\
(0.087)\end{array}$ & $\begin{array}{l}0.185^{* * *} \\
(0.053)\end{array}$ \\
\hline TO & $\begin{array}{c}0.000 \\
(0.000)\end{array}$ & $\begin{array}{l}-0.000^{* * *} \\
(0.000)\end{array}$ & $\begin{array}{c}0.000 \\
(0.000)\end{array}$ & $\begin{array}{c}0.000 \\
(0.000)\end{array}$ & $\begin{array}{c}0.000 \\
(0.000)\end{array}$ & $\begin{array}{c}0.000 \\
(0.000)\end{array}$ \\
\hline EST & $\begin{array}{c}0.000 \\
(0.000)\end{array}$ & $\begin{array}{c}-0.003^{* * *} \\
(0.001)\end{array}$ & $\begin{array}{c}0.000 \\
(0.002)\end{array}$ & $\begin{array}{c}0.001 \\
(0.001)\end{array}$ & $\begin{array}{c}0.000 \\
(0.001)\end{array}$ & $\begin{array}{l}-0.001 \\
(0.001)\end{array}$ \\
\hline Adj. $R^{2}$ & $34.6 \%$ & $52.6 \%$ & $23.5 \%$ & $37.3 \%$ & $49.5 \%$ & $33.4 \%$ \\
\hline
\end{tabular}

Note: ${ }^{* *} p<0.001 ;{ }^{* *} p<0.01 ;{ }^{*} p<0.05$, standard errors in parentheses

Source: Own calculation

Agriculture (-0.085) or Food (-0.069) are still significant, but a less pronounced relationship exists between leverage and operating performance there. Further, we inspect the combined effect of leverage on operating performance modified across firm size 
as well as sectors. We differentiate each sector into small (below-median) and large (abovemedian) segments based on turnover. The results are outlined in Table 6. Leverage proved to be negatively impacting on operating performance in all the sectors in all the subsamples, with a single exception of large companies in the Food sector. An additional analysis for Construction and Engineering, for which the most pronounced effect was detected in Table 5, provides evidence that the relationship is stronger for above-median-sized companies. On the contrary, the sectors with a weaker relationship between leverage and ROA (i.e., Agriculture, Food and Wholesale) exhibit the reverse - operating performance of smaller companies is more affected by leverage.

\subsection{Effect of leverage on operating performance: Additional analysis}

As the investigated period 2006-2017 contains various phases of economic cycles, we also inspect the impact of the existence of the economic downturn on the relationship between leverage and operating performance by adding a dummy variable Crisis and its interaction term with BLAssets:

$$
\begin{aligned}
& \text { ROA }_{i t}=\text { BLAssets }_{i t}+\text { Crisis }_{t}+\text { Crisis }_{t} \times \text { BLAssets }_{i t}+\text { EST }_{i t}+\text { TO }_{i t}+\text { EBITDA }_{i t}+ \\
& +G D P_{t}+3 M P R I B O R_{t}+v_{i}+\varepsilon_{i t}
\end{aligned}
$$

where Crisis is a dummy variable equal to 1 if GDP growth in the respective year is negative and 0 otherwise.

Table 7 shows a significant effect of the interaction term in the whole sample. Outside the crisis period, the effect of leverage on operating performance is negative at -0.113 . During a crisis, the effect is reduced by 0.041 to 0.072 . A similar conclusion can be made in the mid-size subsamples $S 3$ and $S 4$, i.e., the segments where the overall negative effect of leverage on $R O A$ is the most pronounced (see Table 3 ). The remaining size segments, i.e., $S 1, S 2$ and $S 5$, seem to be "immune" to the crisis. In a similar manner, a cross-sector analysis was also performed. A statistically significant "softening" effect of a crisis on the relationship between leverage and performance is found for the Wholesale sector only. ${ }^{6}$ 
Table 6: Effect of leverage on operating performance: analysis by sectors and size

\begin{tabular}{l|c|c|c|c|c|c|c|c|c|c}
\hline & $\begin{array}{c}\text { Agricul- } \\
\text { ture } \\
\text { Small }\end{array}$ & $\begin{array}{c}\text { Agricul- } \\
\text { ture } \\
\text { Large }\end{array}$ & $\begin{array}{c}\text { Construc- } \\
\text { tion } \\
\text { Small }\end{array}$ & $\begin{array}{c}\text { Construc- } \\
\text { tion } \\
\text { Large }\end{array}$ & $\begin{array}{c}\text { Engineer- } \\
\text { ing } \\
\text { Small }\end{array}$ & $\begin{array}{c}\text { Engineer- } \\
\text { ing } \\
\text { Large }\end{array}$ & $\begin{array}{c}\text { Food } \\
\text { Small }\end{array}$ & $\begin{array}{c}\text { Food } \\
\text { Large }\end{array}$ & $\begin{array}{c}\text { Whole- } \\
\text { sale } \\
\text { Small }\end{array}$ & $\begin{array}{c}\text { Whole- } \\
\text { sale } \\
\text { Large }\end{array}$ \\
\hline BLAssets & $-0.119^{* * *}$ & $-0.102^{* * *}$ & $-0.130^{*}$ & $-0.210^{* *}$ & $-0.132^{* * *}$ & $-0.250^{* * *}$ & $-0.119^{* * *}$ & -0.046 & $-0.131^{* * *}$ & $-0.085^{* * *}$ \\
$(0.021)$ & $(0.018)$ & $(0.051)$ & $(0.075)$ & $(0.026)$ & $(0.033)$ & $(0.032)$ & $(0.031)$ & $(0.017)$ & $(0.022)$ \\
\hline \multirow{2}{*}{ EBITDA } & $0.013^{* * *}$ & $0.003^{* * *}$ & $0.003^{* * * *}$ & $0.003^{* * *}$ & $0.020^{* * *}$ & $0.000^{* * *}$ & $0.011^{* * *}$ & $0.001^{* * *}$ & $0.021^{* * *}$ & $0.000^{* * *}$ \\
\hline \multirow{2}{*}{ 3MPRIBOR } & $(0.001)$ & $(0.000)$ & $(0.001)$ & $(0.000)$ & $(0.001)$ & $(0.000)$ & $(0.001)$ & $(0.000)$ & $(0.001)$ & $(0.000)$ \\
\hline \multirow{2}{*}{ GDP } & 0.034 & 0.171 & 0.989 & 1.217 & 0.458 & 0.110 & 0.288 & 0.076 & $0.426^{*}$ & $1.295^{* * *}$ \\
& $(0.198)$ & $(0.127)$ & $(0.642)$ & $(0.655)$ & $(0.414)$ & $(0.374)$ & $(0.395)$ & $(0.232)$ & $(0.215)$ & $(0.181)$ \\
\hline \multirow{2}{*}{ TO } & -0.142 & $-0.131^{* *}$ & 0.050 & $0.470^{*}$ & 0.081 & 0.159 & 0.158 & $0.201^{*}$ & 0.120 & $0.234^{* * *}$ \\
& $(0.080)$ & $(0.040)$ & $(0.228)$ & $(0.239)$ & $(0.116)$ & $(0.109)$ & $(0.129)$ & $(0.084)$ & $(0.069)$ & $(0.060)$ \\
\hline \multirow{2}{*}{ EST } & -0.001 & $-0.000^{* * *}$ & 0.000 & $-0.000^{*}$ & $-0.001^{* * *}$ & 0.000 & $-0.000^{*}$ & $-0.000^{*}$ & $-0.000^{* * *}$ & 0.000 \\
& $(0.000)$ & $(0.000)$ & $(0.000)$ & $(0.000)$ & $(0.000)$ & $(0.000)$ & $(0.000)$ & $(0.000)$ & $(0.000)$ & $(0.000)$ \\
\hline Adj. $R^{2}$ & $-0.004^{* * *}$ & $-0.001^{*}$ & 0.001 & 0.000 & -0.002 & 0.001 & -0.003 & 0.000 & $-0.002^{* *}$ & 0.001 \\
\hline
\end{tabular}

Note: ${ }^{* *} p<0.001 ;{ }^{* *} p<0.01 ;{ }^{*} p<0.05$, standard errors in parentheses

Source: Own calculation

Table 7: Effect of economic crises: analysis by size segments

\begin{tabular}{l|c|c|c|c|c|c}
\hline & All_Ind & S1 & S2 & S3 & S4 & S5 \\
\hline \multirow{2}{*}{ BLAssets } & $-0.113^{* * *}$ & $-0.105^{* * *}$ & $-0.120^{* * *}$ & $-0.132^{* * *}$ & $-0.152^{* * *}$ & $-0.106^{* * *}$ \\
& $(0.008)$ & $(0.015)$ & $(0.014)$ & $(0.014)$ & $(0.016)$ & $(0.024)$ \\
\hline \multirow{2}{*}{ Crisis } & $-0.006^{*}$ & -0.013 & 0.002 & -0.001 & -0.001 & 0.007 \\
& $(0.003)$ & $(0.008)$ & $(0.005)$ & $(0.004)$ & $(0.004)$ & $(0.006)$ \\
\hline \multirow{2}{*}{ BLAssets*Crisis } & $0.041^{* * *}$ & 0.032 & 0.015 & $0.036^{* *}$ & $0.042^{* *}$ & -0.002 \\
& $(0.009)$ & $(0.020)$ & $(0.016)$ & $(0.013)$ & $(0.016)$ & $(0.022)$ \\
\hline \multirow{2}{*}{ EBITDA } & $0.000^{* *}$ & $0.005^{* * *}$ & $0.015^{* * *}$ & $0.005^{* * *}$ & $0.001^{* * *}$ & $0.000^{* *}$ \\
& $(0.000)$ & $(0.000)$ & $(0.000)$ & $(0.000)$ & $(0.000)$ & $(0.000)$ \\
\hline \multirow{2}{*}{ 3MPRIBOR } & $0.613^{* * *}$ & 0.288 & $0.422^{*}$ & $0.330^{*}$ & $0.554^{* * *}$ & $0.531^{* *}$ \\
\hline \multirow{2}{*}{ GDP } & $(0.089)$ & $(0.207)$ & $(0.187)$ & $(0.133)$ & $(0.129)$ & $(0.206)$ \\
\hline \multirow{2}{*}{ TO } & $0.200^{* * *}$ & 0.091 & 0.150 & $0.306^{* * *}$ & $0.302^{* * *}$ & 0.184 \\
& $(0.044)$ & $(0.111)$ & $(0.083)$ & $(0.073)$ & $(0.069)$ & $(0.094)$ \\
\hline \multirow{2}{*}{ EST } & 0.000 & $0.001^{* * *}$ & 0.000 & 0.000 & $-0.000^{* * *}$ & 0.000 \\
\hline \multirow{2}{*}{ Adj. $\boldsymbol{R}^{2}$} & $(0.000)$ & $(0.000)$ & $(0.000)$ & $(0.000)$ & $(0.000)$ & $(0.000)$ \\
\hline
\end{tabular}

Note: ${ }^{* *} p<0.001 ;{ }^{* *} p<0.01 ;{ }^{*} p<0.05$, standard errors in parentheses

Source: Own calculation 
Another problematic stage is the monetary expansion of the CNB and its foreign exchange interventions ${ }^{7}$, resulting, e.g., in only an infinitesimal foreign exchange risk exposure in the case of EUR-denominated trades and in an enormous increase in money base.

The original Equation (1) is amended in the following way:

$$
\begin{aligned}
& R_{\text {OAt }}=\text { BLAssets }_{i t}+F X_{t}+F X_{t} \times \text { BLAssets }_{i t}+E S T_{i t}+T O_{i t}+E B I T D A_{i t}+G D P_{t}+ \\
& +3 M P R I B O R_{t}+v_{i}+\varepsilon_{i t}
\end{aligned}
$$

where FX is a dummy variable equal to 1 during the period 2014-2016 and 0 otherwise. We find that the negative relationship between leverage and operating performance is slightly softened in the period of FX commitment (from -0.116 to -0.080 ) in the whole sample. In the size segment analysis, we have not found any significantly different relationship between leverage and $R O A$ in 2014-2016 as compared to the entire period in any of the segments. Finally, the sector analysis reveals that the change in the magnitude of the relationship between leverage and ROA is only significant for the Construction sector. ${ }^{8}$

\subsection{Robustness checks}

We perform multiple robustness tests on the entire sample in order to address potential endogeneity (and reverse causality) in the relationship between leverage and a company's operating performance. We start with inspection of the inter-temporal relationship between leverage and operating performance, where the main independent variable BLAssets is defined as a lagged value. We detect that the negative effect of leverage measured by the ratio of total bank loans to total assets remains, albeit with lower magnitude and significance. In the second robustness analysis, we use the first difference of BLAssets. Increasing the leverage vis-à-vis the previous period has again a significantly negative effect on the current year's operating performance. Finally, we follow Vithessonthi and Tongurai (2015) or Xu (2012) and employ a two-stage least-squares (2SLS) approach to test for the endogeneity issue using tangibility as the instrumental variable. The tangibility variable is constructed as ratio of fixed assets to total assets. The variable has been shown to be a suitable instrumental variable for leverage since fixed assets are frequently used as a collateral for bank loans. Furthermore, tangibility shows limited correlation

7 For the purposes of this chapter, we define the period of Czech National Bank FX interventions as the period from 2014 to 2016 , as annual reports cannot be matched exactly to the start (7 November 2013) and the end (6 April 2017) of the interventions.

8 Once again, results are not reported, but they are available upon request. 
(correlation coefficient -0.02 ) with operating performance, which again suggests a viable choice. Again, the coefficient of leverage remains significant and negative as suggested by our core analysis. All three additional models are presented in Table 8. Finally, the baseline model (Equation 1) has been run using the traditional measure of ROA (based on EBIT); the results across segments and sectors do not differ substantially in terms of significance as well as coefficient values, and most importantly, leverage again shows a negative relationship to operating performance. ${ }^{9}$

Table 8: Robustness and endogeneity checks

\begin{tabular}{|c|c|c|c|}
\hline & $\begin{array}{l}\text { Lagged BLAssets } \\
\text { Equation } 4\end{array}$ & $\begin{array}{c}\text { First-differenced BLAssets } \\
\text { Equation } 5\end{array}$ & $\begin{array}{c}\text { Instrumental variable } \\
\text { Equation } 6+7\end{array}$ \\
\hline BLAssets (t-1) & $\begin{array}{l}-0.011^{\circ} \\
(0.008)\end{array}$ & - & - \\
\hline Diff BLAssets & - & $\begin{array}{l}-0.107^{* * *} \\
(0.006)\end{array}$ & - \\
\hline BLAssetsIV & - & - & $\begin{array}{l}-0.246^{* * *} \\
(0.028)\end{array}$ \\
\hline EBITDAmn & $\begin{array}{l}0.000 * * \\
(0.000)\end{array}$ & $\begin{array}{l}0.000 * * \\
(0.000)\end{array}$ & $\begin{array}{l}0.000 * * * \\
(0.000)\end{array}$ \\
\hline X3MPRIBOR & $\begin{array}{l}0.768 * * * \\
(0.105)\end{array}$ & $\begin{array}{l}0.889 * * * \\
(0.103)\end{array}$ & $\begin{array}{l}0.592 * * * \\
(0.095)\end{array}$ \\
\hline GDP & $\begin{array}{l}0.128 * * * \\
(0.033)\end{array}$ & $\begin{array}{l}0.120 * * * \\
(0.033)\end{array}$ & $\begin{array}{l}0.126 * * * \\
(0.033)\end{array}$ \\
\hline TOmn & $\begin{array}{l}0.000 \\
(0.000)\end{array}$ & $\begin{array}{c}0.000 \\
(0.000)\end{array}$ & $\begin{array}{c}0.000 \\
(0.000)\end{array}$ \\
\hline EST & $\begin{array}{l}0.001^{* *} \\
(0.000)\end{array}$ & $\begin{array}{l}0.002 * * * \\
(0.000)\end{array}$ & $\begin{array}{l}0.000 \\
(0.000)\end{array}$ \\
\hline Adj. $R^{2}$ & $35.9 \%$ & $36.9 \%$ & $32.8 \%$ \\
\hline
\end{tabular}

Note: ${ }^{* * *} p<0.001 ;{ }^{* *} p<0.01 ;{ }^{*} p<0.05,{ }^{\circ} p<0.10$, standard errors in parentheses. Source: Own calculation

9 Tabulated results are available upon request. 


\section{Conclusion}

Consistent with most previous studies, we found a significant negative relationship between operating performance and financial leverage of Czech firms. The relationship holds for the entire dataset, as well as across all the size segments and industry sectors. The explanation can be based on the development of key performance indicators. The average EBITDA of our sample started to decrease in 2010, despite an increase in the average turnover and average amount of bank loans during the same period. For a variety of reasons, even the economic boom of 2014 did not help the corporate segment to maintain stable margins. Furthermore, higher working capital needs and higher investments in production capacities, accompanied with a decline in EBITDA as an internal source of financing, forced the corporate sector to cover the negative balances in the operating and investment cash flow from external sources, mainly in the form of new interest-bearing bank debt, thus contributing to a deterioration in profitability.

We also find that the samples representing smaller companies have higher average financial leverage accompanied by a higher EBITDA margin. One plausible interpretation may be that the financial constraint called the "SME financial gap" (OECD, 2006) is prevalent and is more severe for the smallest companies. Although these companies are able to generate a higher EBITDA margin, they are not able to benefit from it through their own organic growth or through a higher share of non-bank-debt financing in total liabilities. These companies become constrained by the availability of external sources of finance in the form of extended trade credit lines or additional bank financing while facing relatively low equity volumes and limited potential for further equity add-ons and tangibility (to be used for additional collateralisation). This leads to the conclusion that, in the case of the Czech Republic, there is rather satisfactory access to bank debt financing but a lack of equity financing, especially for small companies.

The empirical results of our study, focusing on the banking perspective, thus contribute to a broader understanding of the impact of differences in leverage among different sectors and segments on capital allocation, which is managed predominantly by banks in small open economies (such as the Czech one). Such knowledge is a decisive input for any policymaking on both the national and the corporate level and is essential for making the right decisions respecting unique sector or segment features. In particular, the findings of the study may be relevant during times of uncertainty (such as the current COVID pandemic) to efficiently target the construction of banking products as well as proposed governmental measures providing access to liquidity by differentiating the sectors and segments of national economy based on their specific conditions, affecting the level of sensitivity between leverage and performance. 


\section{References}

Aivazian, V. A., Ge, Y., Qiu, J. (2005). The Impact of Leverage on Firm Investment: Canadian Evidence. Journal of Corporate Finance, 11(1-2), 277-291, https://doi.org/10.1016/ S0929-1199(03)00062-2

Barclay, M. J., Smith, C. W. (1995). The Maturity Structure of Corporate Debt. The Journal of Finance, 50(2), 609-631, https://doi.org/10.1111/j.1540-6261.1995.tb04797.x

Bauer, P. (2004). Determinants of Capital Structure: Empirical Evidence from the Czech Republic. Czech Journal of Economics and Finance, 54(1-2), 2-21.

Beck, N., Katz, J. N. (1995). What to Do (and Not to Do) with Time-Series Cross-Section Data. American Political Science Review, 89(3), 634-647, https://doi.org/10.2307/2082979

Bena, J., Ondko, P. (2012). Financial Development and the Allocation of External Finance. Journal of Empirical Finance, 19(1), 1-25, https://doi.org/10.1016/j.jempfin.2011.11.002

Colombo, E. (2001). Determinants of Corporate Capital Structure: Evidence from Hungarian Firms. Applied Economics, 33(13), 1689-1701, https://doi. org/10.1080/00036840010015057

Črnigoj, M., Mramor, D. (2009). Determinants of Capital Structure in Emerging European Economies: Evidence from Slovenian Firms. Emerging Markets Finance and Trade, 45(1), 72-89, https://doi.org/10.2753/REE1540-496X450105

de Jong, A., Kabir, R., Nguyen, T. T. (2008). Capital Structure Around the World: The Roles of Firm- and Country-specific Determinants. Journal of Banking \& Finance, 32(9), 1954-1969, https://doi.org/10.1016/j.jbankfin.2007.12.034

Delcoure, N. (2007). The Determinants of Capital Structure in Transitional Economies. International Review of Economics \& Finance, 16(3), 400-415, https://doi.org/10.1016/j. iref.2005.03.005

Denis, D. J., Mihov, V. T. (2003). The Choice among Bank Debt, Non-bank Private Debt, and Public Debt: Evidence from New Corporate Borrowings. Journal of Financial Economics, 70(1), 3-28, https://doi.org/10.1016/S0304-405X(03)00140-5

Faulkender, M., Petersen, M. A. (2006). Does the Source of Capital Affect Capital Structure? Review of Financial Studies, 19(1), 45-79, https://doi.org/10.1093/rfs/hhj003

Frank, M. Z., Goyal, V. K. (2009). Capital Structure Decisions: Which Factors Are Reliably Important? Financial Management, 38(1), 1-37, https://doi.org/10.1111/j.1755-053X $.2009 .01026 . x$

Hall, G., Hutchinson, P., Michaelas, N. (2000). Industry Effects on the Determinants of Unquoted SMEs' Capital Structure. International Journal of the Economics of Business, 7(3), 297-312, https://doi.org/10.1080/13571510050197203

Harris, M., Raviv, A. (1990). Capital Structure and the Informational Role of Debt. The Journal of Finance, 45(2), 321-349, https://doi.org/10.1111/j.1540-6261.1990.tb03693.x 
Jõeveer, K. (2013). Firm, Country and Macroeconomic Determinants of Capital Structure: Evidence from Transition Economies. Journal of Comparative Economics, 41(1), 294-308, https://doi.org/10.1016/j.jce.2012.05.001

MacKay, P., Phillips, G. M. (2005). How Does Industry Affect Firm Financial Structure? Review of Financial Studies, 18(4), 1433-1466, https://doi.org/10.1093/rfs/hhi032

Margaritis, D., Psillaki, M. (2008). Capital Structure and Firm Efficiency. Journal of Business Finance \& Accounting, 34(9-10), 1447-1469, https://doi. org/10.1111/j.1468-5957.2007.02056.x

Margaritis, D., Psillaki, M. (2010). Capital Structure, Equity Ownership and Firm Performance. Journal of Banking \& Finance, 34(3), 621-632, https://doi.org/10.1016/j. jbankfin.2009.08.023

Mateev, M., Poutziouris, P., Ivanov, K. (2013). On the Determinants of SME Capital Structure in Central and Eastern Europe: A Dynamic Panel Analysis. Research in International Business and Finance, 27(1), 28-51, https://doi.org/10.1016/j.ribaf.2012.05.002

Mazur, K. (2007). The Determinants of Capital Structure Choice: Evidence from Polish Companies. International Advances in Economic Research, 13(4), 495-514, https://doi.org/10.1007/s11294-007-9114-y

Mizen, P., Tsoukas, S. (2012). The Response of the External Finance Premium in Asian Corporate Bond Markets to Financial Characteristics, Financial Constraints and Two Financial Crises. Journal of Banking \& Finance, 36(11), 3048-3059, https://doi.org/10.1016/j.jbankfin.2012.07.005

Modigliani, F., Miller, M. H. (1958). The Cost of Capital, Corporation Finance and the Theory of Investment. The American Economic Review, 48(3), 261-297.

Moore, W., Craigwell, R. (2003). The Relationship between Commercial Banks' Interest Rates and Loan Sizes: Evidence from a Small Open Economy. Applied Financial Economics, 13(4), 257-266, https://doi.org/10.1080/09603100110116434

Myers, S. C. (1984). The Capital Structure Puzzle. The Journal of Finance, 39(3), 574-592, https://doi.org/10.1111/j.1540-6261.1984.tb03646.x

Nivorozhkin, E. (2004). The Dynamics of Capital Structure in Transition Economies. Economics of Planning, 37(1), 25-45, https://doi.org/10.1007/s10644-004-1056-2

OECD (2006). The SME Financing Gap: Theory and Evidence. Financial Market Trends, 2006(2), 87-97, https://doi.org/10.1787/fmt-v2006-art11-en

Prášilová, P. (2012). Determinanty kapitálové struktury českých podniků. Ekonomie a Management, 15(1), 89-104.

Psillaki, M., Daskalakis, N. (2009). Are the Determinants of Capital Structure Country or Firm Specific? Small Business Economics, 33(3), 319-333, https://doi.org/10.1007/ s11187-008-9103-4

Ross, S. A. (1977). The Determination of Financial Structure: The Incentive-Signalling Approach. The Bell Journal of Economics, 8(1), 23-40, https://doi.org/10.2307/3003485 
Short, H. (1994). Ownership, Control, Financial Structure and the Performance of Firms. Journal of Economic Surveys, 8(3), 203-249, https://doi.org/10.1111/j.1467-6419.1994. tb00102.x

Šarlija, N., Harc, M. (2016). Capital Structure Determinants of Small and Medium Enterprises in Croatia. Managing Global Transitions, 14(3), 251-266.

Talberg, M., Winge, C., Frydenberg, S., et al. (2008). Capital Structure across Industries. International Journal of the Economics of Business, 15(2), 181-200, https://doi.org/10.1080/13571510802134304

Titman, S., Wessels, R. (1988). The Determinants of Capital Structure Choice. The Journal of Finance, 43(1), 1-19, https://doi.org/10.1111/j.1540-6261.1988.tb02585.x

Vithessonthi, C., Tongurai, J. (2015). The Effect of Firm Size on the Leverage-performance Relationship during the Financial Crisis of 2007-2009. Journal of Multinational Financial Management, 29, 1-29, https://doi.org/10.1016/j.mulfin.2014.11.001

Xu, J. (2012). Profitability and Capital Structure: Evidence from Import Penetration. Journal of Financial Economics, 106(2), 427-446, https://doi.org/10.1016/j.jfineco.2012.05.015 